\title{
PRELIMINARY STUDIES ON CHANGES IN DISTRIBUTION OF AQUATIC MACROPHYTES IN THE LUNUWILA TANK IN 1991-1993, AFTER INTRODUCTION OF CYRTOBAGOUS SALVINIAE TO CONTROL SALVINIA MOLESTA
}

\author{
S.M. SOLANGAARACHCHI and W.M.D.S.K. PERERA \\ Department of Botany, University of Kelaniya, Kelaniya.
}

(Received: 31 May 1995; accepted: 02 February 1996)

\begin{abstract}
Monthly abundance (in terms of percentage frequency and percentage cover) of macrophytic species, from August, 1991 to September, 1993, were studied using $1 \times 1 \mathrm{~m}^{2}$ quadrats in the Lunuwila tank, into which Cyrtobagous salviniae, had been introduced to control Salvinia molesta. The results indicate that Salvinia molesta, Nelumbium sp. and Nymphaea lotus were the main competing species during the study period, and $S$. molesta was the main controlling species. Submerged species, Hydrilla verticillata, Vallisnaria spiralis and Utricularia flexuosa were found growing in the absence or poor growth of S. molesta. The tank dried completely during February to April 1991 and all species except Nelumbium sp. disappeared due to desiccation. All the species however, reappeared after the rain, with Salvinia molesta taking six months to reappear. During July and August 1992, leaves of Nelumbium sp. were attacked by a Lepidopteran caterpillar and a Dipteran larva (leaf miner). Nymphaea lotus was found subsequently. The results suggest that $S$. molesta threat has not been eliminated through biological control and also that the community change in macrophytes in the water body depend on the initial species composition, their abundance, rainfall pattern, and natural predatory activities on macrophytes.
\end{abstract}

Key words: Aquatic macrophytes, Cyrtobagous salviniae, Lunuwila, Salvinia molesta.

\section{INTRODUCTION}

Of about 50,000 reservoirs in Sri.Lanka, almost all are infested with aquatic weeds. The presence of aquatic macrophytes in waterways and reservoirs affects agriculture for many reasons. Deoxygenation of water, reduction in fish productivity, choking of irrigation channels and retardation of the flow of water, increased siltation, promoting breeding of mosquitoes, and competition with rice are some of the drawbacks.

Among the common aquatic weeds, the free floating fern Salvinia molesta D.S. Mitchell which had been introduced into Sri Lanka in $1931,{ }^{1}$ has become a serious threat to lowland water bodies. In 1950 s the weed was controlled by physical removal and herbicides. ${ }^{2}$ However, in the 1980 s about $25 \%$ of the country's reservoirs were infested with $S$. molesta.$^{3}$ Biological control of S. molesta in 1973, with a grasshopper, Paulinia acuminata De Geer was a failure. ${ }^{4}$ However, following the rapid control of $S$. molesta in tropical Australia ${ }^{5}$ and Papua New Guinea ${ }^{6}$ with a beetle (Cyrtobagous salviniae Calder \& Sands 
(Coleoptera : Curculionidae), the beetle was introduced to our waters in 1987. This project was funded by the Australian Centre for International Agricultural Research and involved collaboration between CSIRO Australia and the Department of Agriculture, Sri Lanka and the University of Kelaniya. It was reported that $80 \%$ of $S$. molesta infestation in Sri Lanka had been removed by late 1990. ${ }^{7}$ Following the introduction of the beetle it was expected that the water bodies would be free of Salvinia, leading other macrophytes to dominate the habitat. Depending on the competitive ability of other species, different communities may occur successively, some of which could also become problematic weeds. If the changing pattern of the communities could be known in advance, one could plan how and when to control each species, so that the water body is kept free of weeds.

Succession of aquatic macrophytes has been recorded by many authors in different countries in long term studies. ${ }^{8-12}$ Osborne and Leach ${ }^{10}$ studied the changes in the distribution of aquatic macrophytes in Waigani Lake in Papua New Guinea, from 1942 to 1981, Obot and Mbagwu ${ }^{11}$ studied macrophytic succession in Jebba Lake, Nigeria, from 1983 to 1987 and Kzyzanek et al. ${ }^{12}$ investigated the community changes of macrophytes in the Goczalkowice reservoir on the River Vistula in Poland in the years 1955 - 1982. The present paper describes the results of a research project, carried out to study the pattern of community change in a selected water body (Lunuwila tank) into which the biological controlling agent has been introduced. The study was carried out from August 1991 to September 1993.

\section{METHODS AND MATERIALS}

Study Area: The Lunuwila tank which is a man-made one, is situated close to the Lunuwila-Kirimatiyana road in Lunuwila, North-western province and lies in the Intermediate rainfall zone. The surface area is $4.80 \mathrm{ha}$ (12 acres) and the water storage capacity is $74006 \mathrm{~m}^{3}$ (60 Acfts), which irrigates $40.45 \mathrm{ha}$ ( 100 acres) of paddy fields. The catchment area is about 1295 ha (5.0 square miles). Maximum and average depths are $2.25 \mathrm{~m}$ and $1.50 \mathrm{~m}$ respectively. A small island supporting about 20 coconut trees is also situated in the centre of this tank. The main sources of water are rain and ground water. During droughts the tank dries up completely. In addition to irrigation of rice fields the tank is used by the people, for washing, bathing, fishing and cleaning of animals.

Colection of plants: Plant species were collected from the water body and identified by comparing with specimens in the National Herbarium, Peradeniya and by reference to Dassanayake and Fosberg. ${ }^{13}$

Changes in the abundance of aquatic macrophytes were studied by estimating the percentage frequency and percentage cover of each species. As it was observed that the distribution of macrophytic vegetation was not homogeneous 
throughout the water body, three contrasting sites (Sites A, B \& C) were selected. Monthly samples were taken from August 1991 to September, 1993, by laying nine $1 \times 1 \mathrm{~m}$ quadrats randomly at each site. Sampling was restricted upto $6 \mathrm{~m}$ from the edge towards the centre, as it was realized by visual observation, that this distance represented the whole vegetation. Random positions were located at each site by considering two co-ordinates and referring to a random numbers table. Measurements were made with the least disturbance to the free floating and submerged vegetation at each sampling.

The quadrat was subdivided into 100 units, each with an area of $0.01 \mathrm{~m}^{2}$ by using metal wires, and the frequency was estimated by counting the number of subunits, in which each species was present. Then the percentage frequency was calculated. The cover which is usually expressed as a percentage, was estimated by using a cover frame. In this method a number of points with regular intervals were considered and the number of points by which each species was touched, counted. This was estimated by using the same quadrat area used for the estimation of the frequency. Monthly rainfall data were also obtained from the Meteorology Department.

\section{RESULTS}

Aquatic macrophytic species found in the tank were as follows :

Alternanthera sessilis L. (Amaranthaceae); Aponogeton crispus Thunb. (Aponogetonaceae); Pistia stratiotes L. (Araceae); Limnocharis flava (Butamaceae); Commelina diffusa Burm. (Commelinaceae); Ipomoea aquatica Forsk (Convolvulaceae); Cyperus cephalotes (Vahl.)Enum., Cyperus compressus L., Cyperus difformis L., Cyperus javanicus Houtt, Cyperus melanosperma, Cyperus platystylis (R.) Br., Eleocharis geniculata (L.) Roem \& Schult, Eleocharis lankana T. Koyama, Fimbrystylis miliacea (L.)Vahl, Mariscus dubius (Rottdoell) Kukenth., Pycreus sanguinolentus (Vahl) Nees, Rhynchospora corymbosa (L.) Britt, Schoenoplectus articulatus (L.) Palla, Scleria poaeformis Retz. (Cyperaceae); Eriocaulon sexangulare L. (Eriocaulaceae); Axonopus affinis, Axonopus compresses (Sw.) Beauv. (Graminae); Hydrilla verticillata Casp., Vallisnaria spiralis L. (Hydrocharideae); Utricularia flexuosa Vahl (Lentibulariaceae); Nymphoides hydrophylla (Lour.) Kuntze, Nymphoides indica (L.) Kuntze (Menyanthaceae); Naias graminea Del. (Naiadeae); Nelumbium speciosum Willd., Nymphaea lotus L., Nymphaea nouchali (Nymphaeceae); Jussiaea repens L. (Onagraceae); Brachiaria ramota, Hygroriza aristata (Retz.) Nees, Hymenachne acutigluma, Isachne globosa (Thumb.) Kuntze (Poaceae); Monochoria vaginalis (Presl) Reliq. (Pontederiaceae); Ceratopteris thalictroides Brongn. (Pteridaceae); Azolla pinnata, Salvinia molesta D.S. Mitchell (Salviniaceae); Bacopa monnieri (L.) Pennell, Limnophila aquatica (Roxb.) Alston (Scrophulariaceae); Oldenlandia herbacea (Roxb, Fl, Ino, ed, Wall) (Umbelliferae); and Xyris sp. (Xyrideae). 
Forty five species including 42 species of angiosperms belonging to 20 families and three Pteridophytes were recorded. However, the distribution varied between sites. Some species were found in all the three sites, but some were found in certain sites only. However, only a few species were found to be abundant, while the others were found at very low abundance levels.

The most abundant macrophyte species were Salvinia molesta, Nymphaea lotus, Nymphaea nouchali, Nelumbium speciosum, Fimbrystylis miliacea, Brachiaria ramota, Jussiaea repens, Hydrilla verticillata, Hymenechne acutigluma, Nymphoides hydrophylla, Utricularia flexuosa, Azolla pinnata, Isachne globosa, Ipomoea aquatica, Vallisnaria spiralis and Bacopa monnieri.

Figs. 1a-f show the variations in abundance of aquatic macrophytes in terms of percentage frequency and percentage cover, at each site. The percentage frequency and percentage cover showed similar patterns. Therefore, only the percentage frequency data will be described in detail. Rainfall distribution experienced by the tank during the study period is given in fig.2 (obtained from the Meteorological Department, Sri Lanka). As the rainfall distribution shows, the tank dried for two periods during the present study, i.e. all three sites dried completely during February - April 1992, and site A dried up during August 1993, and , during this dry spell sites B \& C were not completely dried and the macrophytes grew in the remaining water. Therefore, sampling could not be carried out at dried sites during the drought.

At all three sites the most common species were found to be the same. However, Bacopa monnieri was found only at site $\mathrm{C}$ though poorly abundant. Because the abundance of each species was found to be slightly different at different sites, the data are illustrated for each site separately.

\section{DISCUSSION}

In many studies abundance has been estimated in terms of the biomass of each species. 8,9 However, in the present study this was avoided because the removal of plants at each sampling could have had an impact on the remaining species in the community. The "density" of each species was also not considered as it was difficult to identify an individual in clonally spreading plants such as Salvinia molesta, Hydrilla verticillata and Utricularia flexuosa.

The results show that the species composition and their abundance varied from place to place in the reservoir at a given time. Therefore, it is more meaningful to describe the results of the three sites separately. The weed $S$. molesta was found to be the main competing species. Nelumbium sp. and Nymphaea lotus were other prominent competing species and their abundance increased when the abundance of $S$. molesta decreased. 


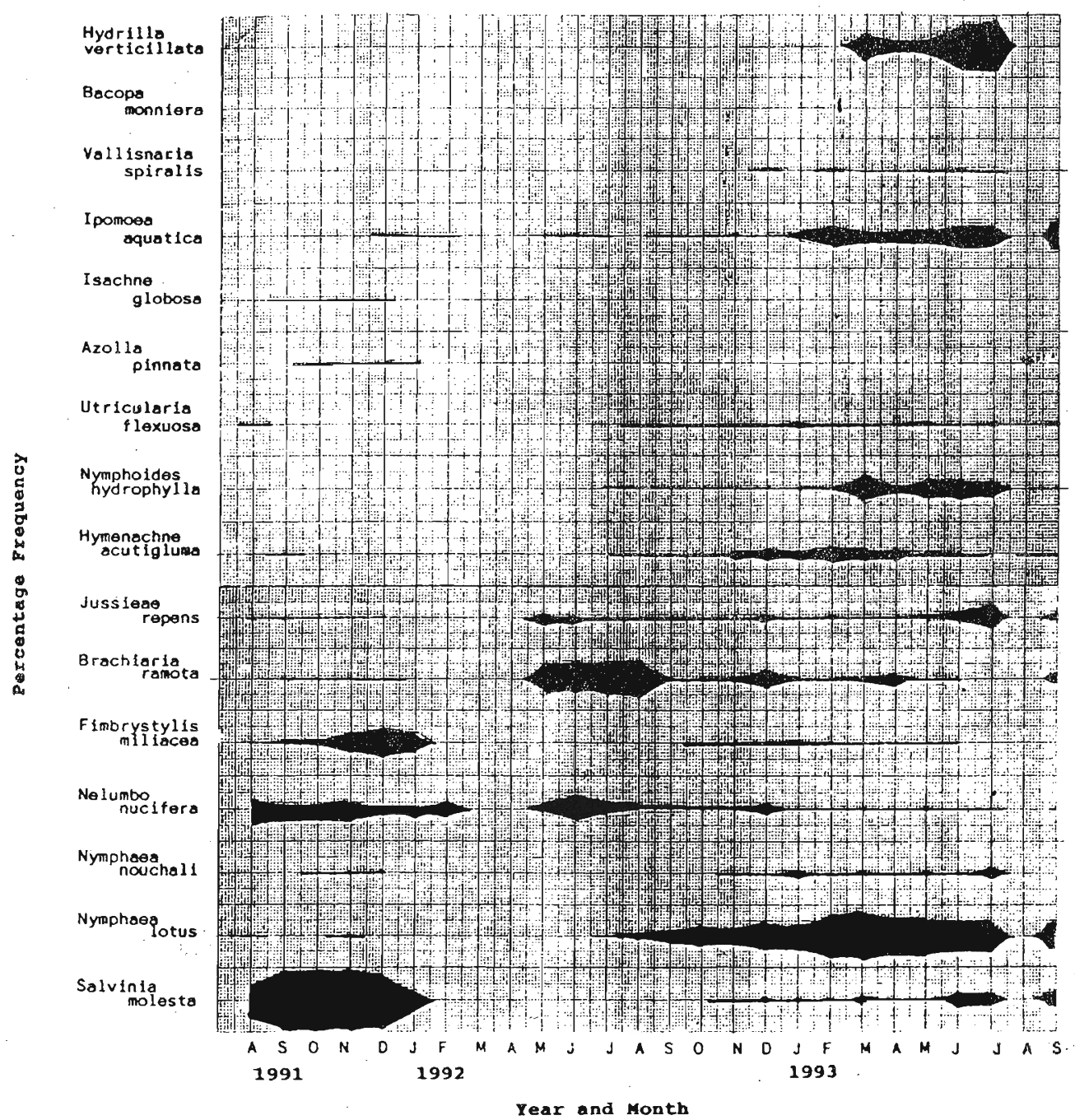

Figure 1a - Site A 


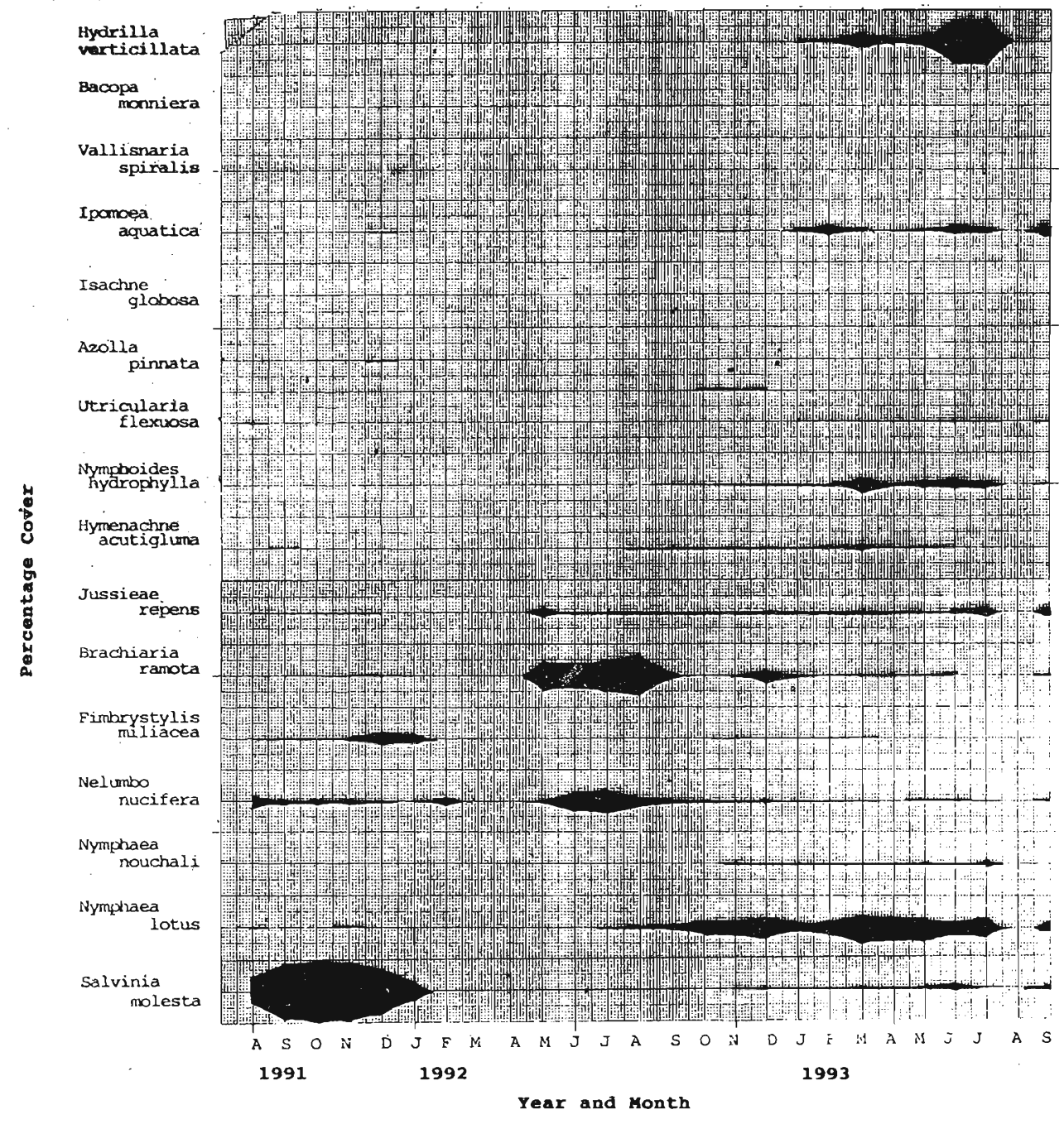

Figure 1b - Site A 


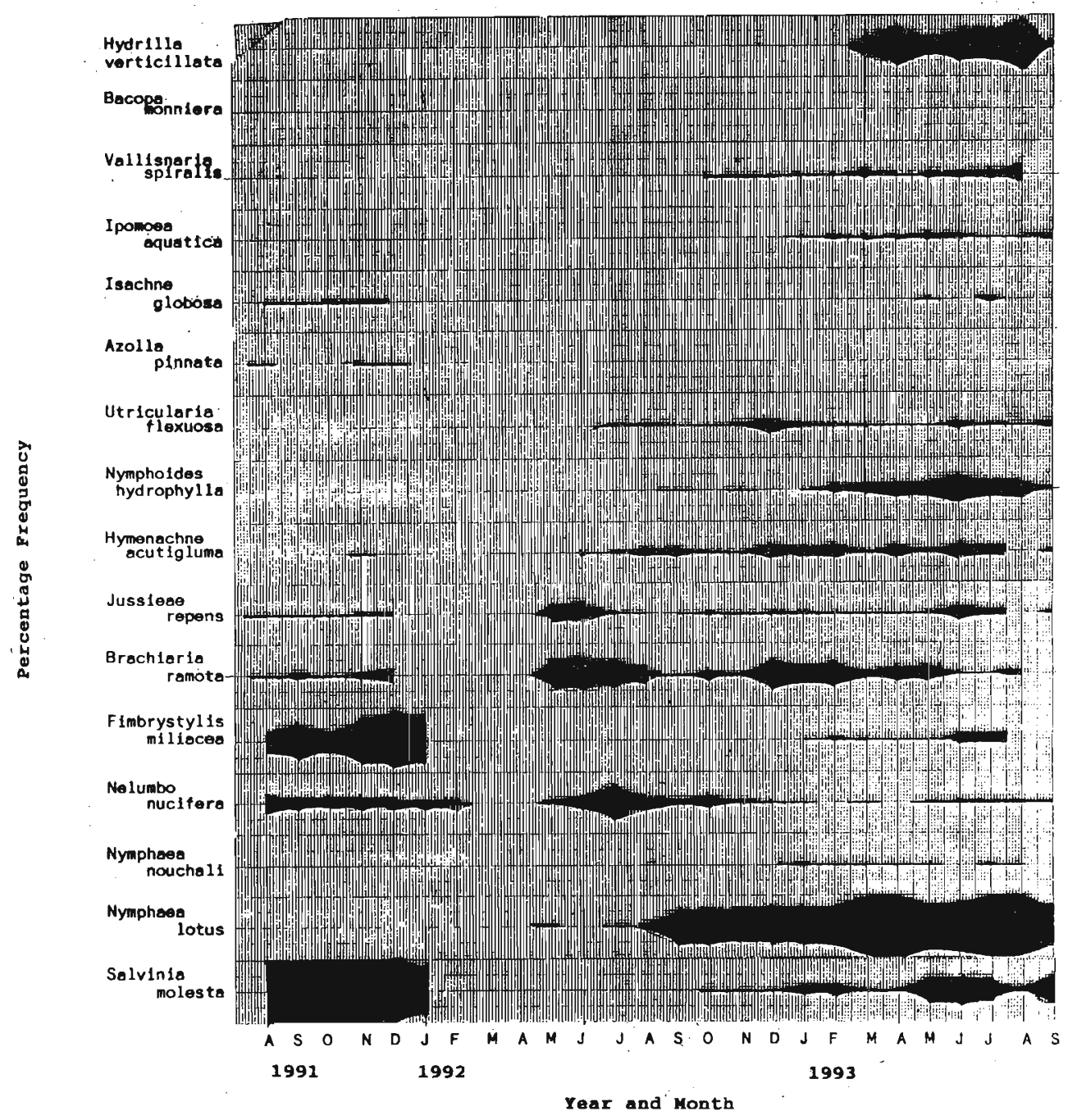

Figure 1c - Site B 


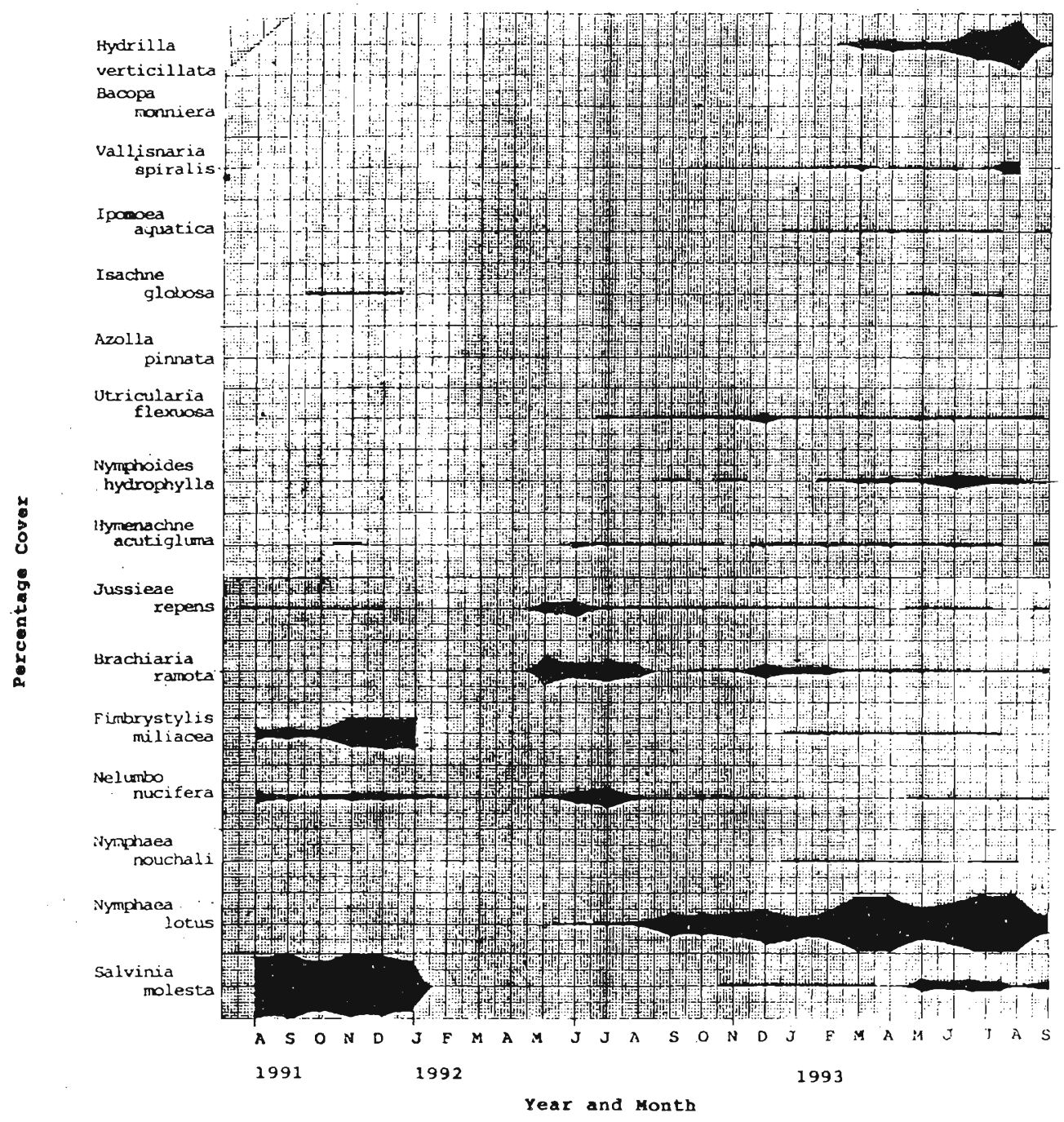

Figure 1d - Site B 


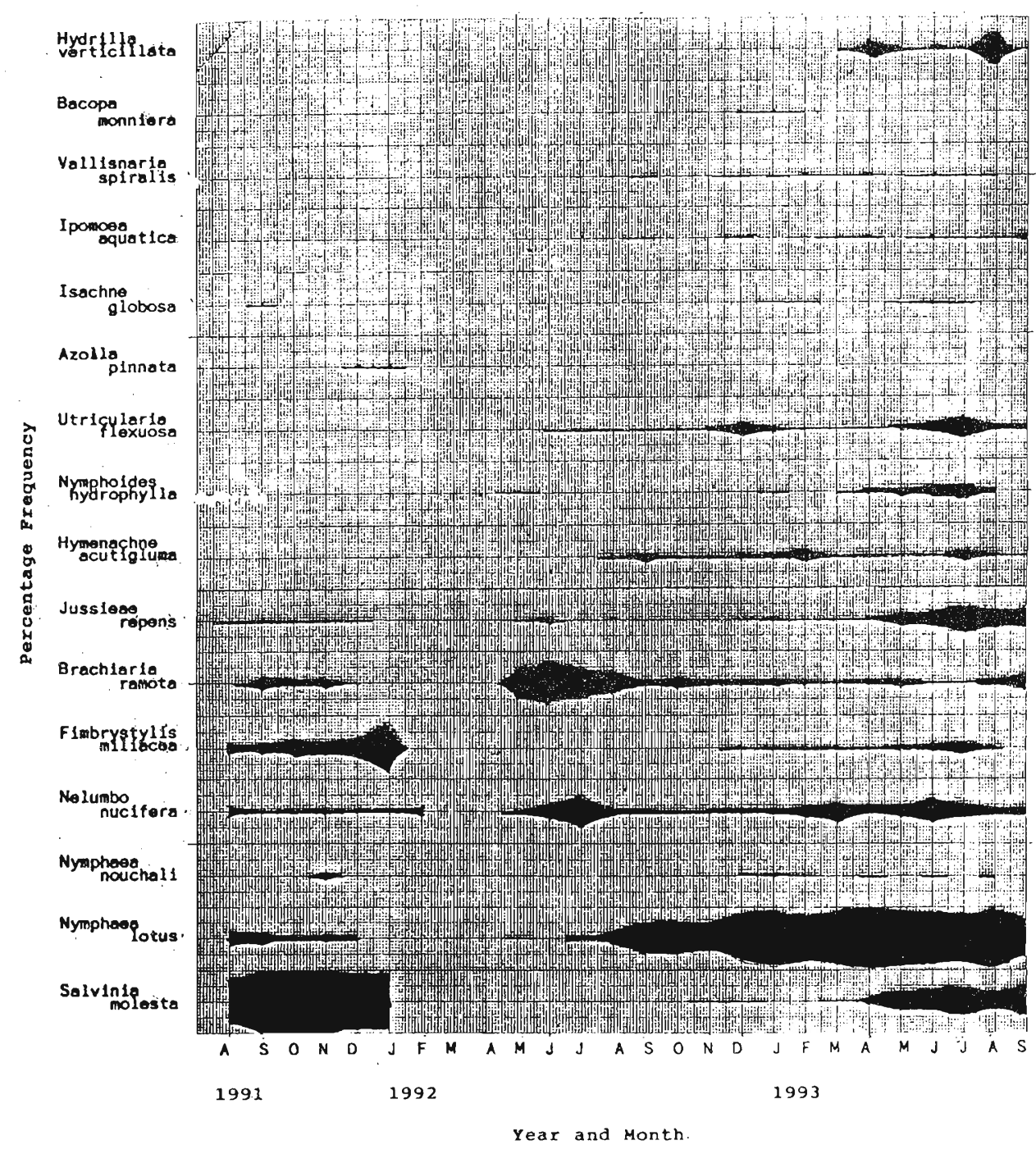

Figure le - Site C 


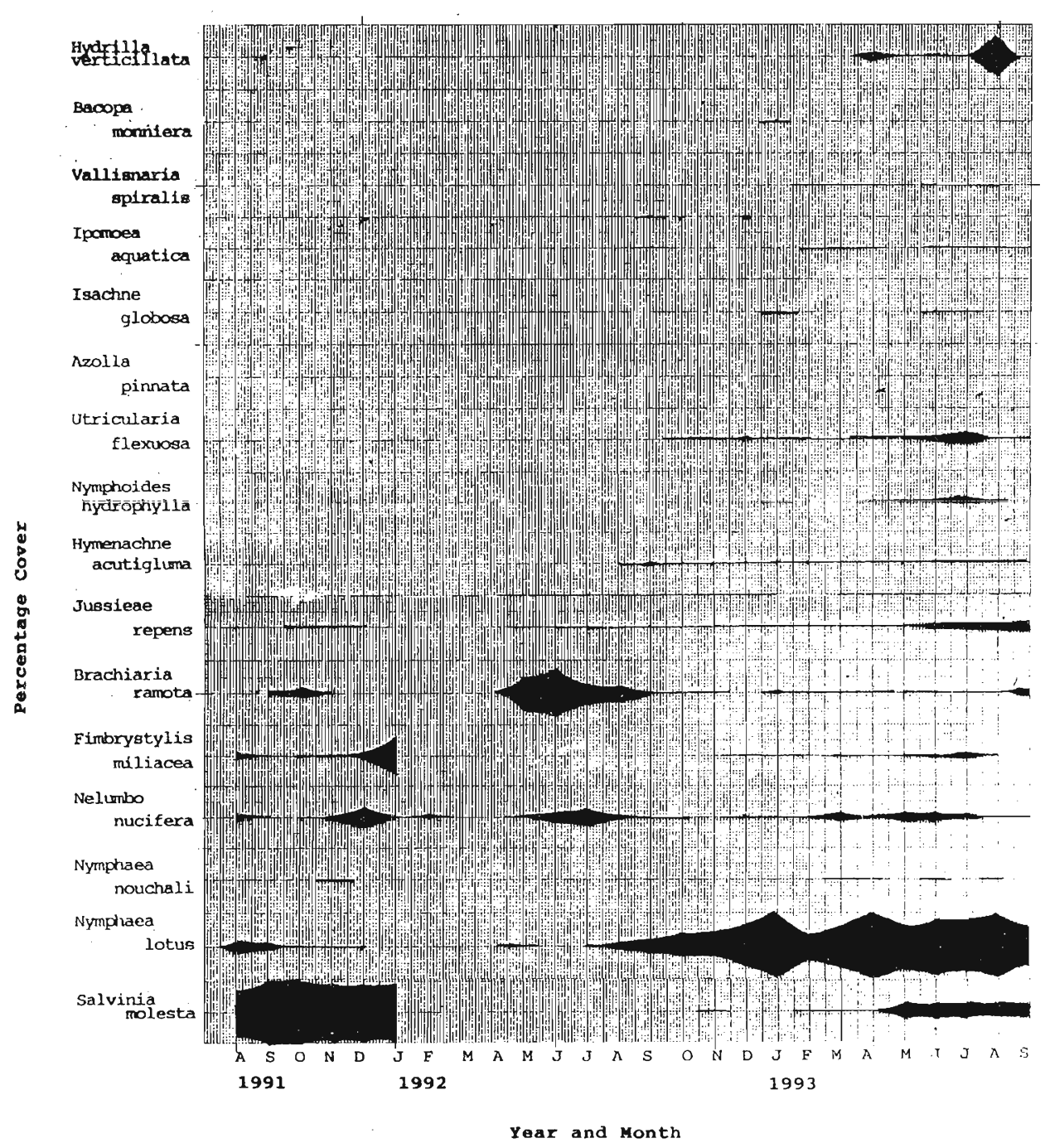

Figure If - Site C

Figure 1a-f: Variation in Percentage Frequency and Percentage Cover of aquatic macrophytes found at three sites $(A, B \& C)$ in the Lunuwila tank from August 1991 to September $1993(n=9)$. Two divisions on the $Y$ axis represent $100 \%$ Frequency or Cover $(a, b, c, d$, e and $f$ - percentage frequency and percentage cover at sites $A, B \& C$ respectively). 


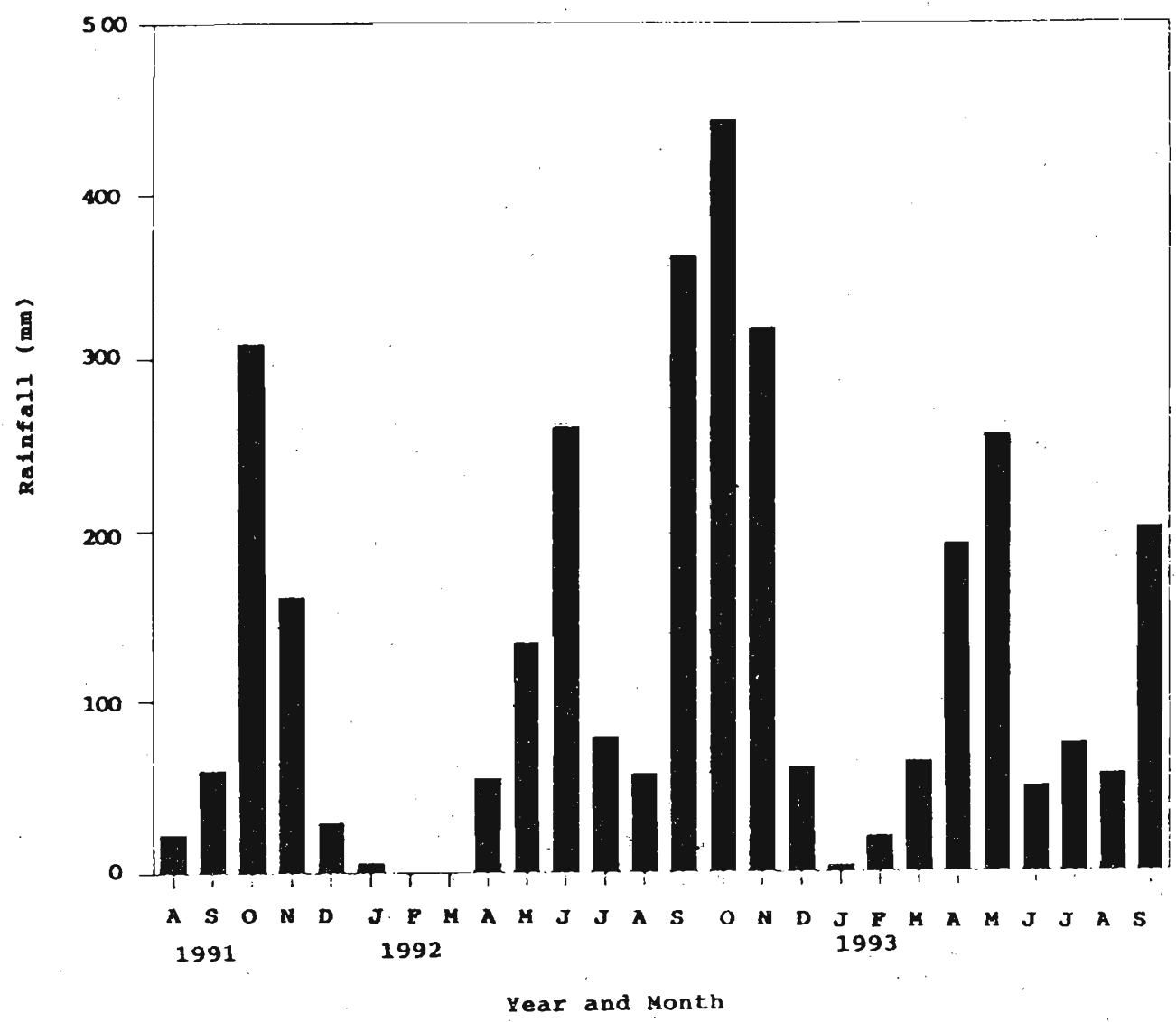

Figure 2: Rainfall (mm) distribution experienced by the Lunuwila tank from August 1991 to September 1993 (Source: Meteorology Department, Sri Lanka).

Fimbrystylis miliacea could only be found growing on thick mats of S. molesta. Therefore, the thicker the $S$. molesta mats the more abundant was $F$. miliacea. Submerged species Hydrilla verticillata, Vallisnaria spiralis and Utricularia flexuosa could grow in the absence or poor abundance of S. molesta. This implies that $S$. molesta strongly controls the growth of submerged plants presumably due to poor light penetration through the formation of thick mats. However, $H y d r i l l a$ sp. grew in the presence of $N$. lotus and poor growth of S. molesta as they penetrate some light through the surface of water. Furthermore, results showed that more species could invade and increase their abundance in the absence or at poor abundance levels of $S$. molesta which further indicated that $S$. molesta was the main competing species. Some grass species such as Brachiaria ramota invaded the water body mainly during the drought, during which they grew on wet soil and their presence continued after the tank was filled due to rain. 
The results also indicate that the growth and succession of macrophytes in the water body are also dependent on rainfall. During the drought when the water body dried up, all plants except Neiumbium sp. died due to desiccation. Following rain, S. molesta reappeared after six months. The reappearance could be due to the regeneration from the desiccated debris or from propagules which might have entered the tank, through water or human and animal interference. However, Nelumbium sp. was the most drought resistant species, and this may presumably be due to the presence of underground perennating parts or rhizomes.

Furthermore, when the drought was short, macrophytic species survived even in little water. This was observed during August, 1993. But prolonged drought (from February - March 1991) dried up the tank completely and as a result most of the species were desiccated and died. On the other hand, it could also be suggested that, if the intensity of rainfall is high, water bodies tend to overflow and as a result, the free floating macrophytes can be washed away. This may also change the species composition and affect the community thereafter. Similar situations may occur if the tank is regularly controlled by opening and closing of sluice gates.

From the present results, it was also evident that Nymphaea lotus could compete with Nelumbium sp. and as a result Nelumbium sp. disappeared with the appearance of Nymphaea lotus which grew abundantly later. However, this occurred when the abundance of $S$. molesta was very poor. The disappearance of Nelumbium sp. coincided (July - September in 1992 and 1993) with the attack on leaves by two insects, i.e. a Lepidopteran caterpillar feeding on Nelumbium sp. leaves above the water surface, and a Dipteran larva, a leaf miner, that attacked floating leaves (the two insects were not identified to their genus level). Death of Nelumbium may have provided the space for Nymphaea lotus. But on the other hand Nymphaea lotus may have the ability to compete with Nelumbium sp. . Therefore, these aspects are worth further studying.

S. molesta was found to be present throughout the period of investigation at Lunuwila tank although the beetle was also found on $S$. molesta plants. This implies that the $S$. molesta weed has not been controlled satisfactorily. It is possible that the population density of the beetle was inadequate to control $S$. molesta, or that palatability of the $S$. molesta plants due to its nitrogen content might not have been satisfactory for the beetle. ${ }^{6,14,15}$ Therefore, it is suggested that continuous monitoring of the biological control of $S$. molesta is required in resevoirs such as Lunuwila. 


\section{Acknowledgement}

We thank NARESA for the research grant (RG/90/WW/01), and C. Kodagoda and Shyamalie Swarnalatha for assistance.

\section{References}

1. Williams R.H. (1956). Salvinia molesta Aubl.: the chemical eradication of a serious aquatic weed in Ceylon. Tropical Agriculture 33: 145-157.

2. Dasanayake M.D. (1976). Noxious aquatic vegetation control in Sri Lanka. In: Aquatic Weeds in South East Asia. (Eds. C.K. Varshney and J. Rzoska) W. Junk, The Hague. pp 51-58.

3. Doeleman J.A. (1989), Biological control of Salvinia molesta in Sri Lanka: an assessment of costs and benefits. Technical Report 12 Canberra, ACIAR. p. 14.

4. Julien M.H. (1987). Biological control of weeds: a world catalogue of agents and their target weeds. CAB11BC, Ascot.

5. Room P.M., Harley K. L.S., Form I. W. \& Sands D.P.A. (1981). Successful biological control of the floating weed Salvinia. Nature 294: 78-80.

6. Room P.M. \& Thomas P. A. (1985). Nitrogen and establishment of a beetle for biological control of the floating weed Salvinia in Papua New Guinea. Journal of Applied Ecology 22: 139-156.

7. Room P.M. \& Fernando I.V.S. (1992). Weed invasions countered by biological control : Salvinia molesta and Eichhornia crassipes in Sri Lanka. Aquatic Botany 42: 99-107.

8. Lauridsen T.L., Jeppesen E. \& Sondergaard M. (1994). Colonization and succession of submerged macrophytes in shallow Lake Vaeng during the first five years following fish manipulation Hydrobiologia 275/276: 233-242.

9. Urbane-Bercic O. \& Blejee A. (1993). Aquatic macrophytes of Lake Bled: changes in species composition distribution and production. Hydrobiologia 262: 189-194.

10. Osborne P.L. \& Leach G.J. (1983). Changes in the distribution of aquatic plants in a tropical swamp. Envirionmental Conservation 10(4): 323-329. 
11. Obot E.A. \& Mbagwu I.G. (1988). Successional patterns of aquatic macrophytes in Jebba Lake, Nigeria. African Journal of Ecology 26: 295-299.

12. Kzyzanek E., Kasza H., Krzanowski W., Kuflikowski T. \& Pajak G. (1986). Succession of communities in the Goczakkowice Dam reservoir in the period 1955-1982. Archives of Hydobiology 106(1): 21-43.

13. Dassanayake M.D. \& Fosberg F.R. (1980). A revised handbook to the flora of Ceylon, I-VI. Amarind Publishing Company, New Delhi.

14. Room P.M. \& Thomas P.A. (1986). Nitrogen, phosphorus and potassium in Salvinia molesta Mitchell in the field : effects of weather, insect damage, fertilizers and age. Aquatic Botany 24: 213-232.

15. Room P.M. , Gunatilake G. A., Shivanathan P. \& Fernando I.V.S. (1989). Control of Salvinia molesta, in Sri Lanka by Cyrtobagous salviniae. Proceedings of the VII International Symposium of Biological Control of Weeds, 6-11March 1988. Rome, Italy. (Ed. E.S. Delfosse) pp. 285-290 (1989). 